\title{
Deep-sea meiofauna communities in Antarctica: structural analysis and relation with the environment
}

\author{
S. Vanhove ${ }^{1, *}$, J. Wittoeck ${ }^{1}$, G. Desmet ${ }^{1}{ }^{1}$ B. Van den Berghe ${ }^{1}$, R. L. Herman ${ }^{1}$, \\ R. P. M. Bak ${ }^{2}$, G. Nieuwland ${ }^{2}$, J. H. Vosjan ${ }^{2}$, A. Boldrin ${ }^{3}$, S. Rabitti ${ }^{3}$, M. Vincx ${ }^{1}$ \\ 'University of Gent, Department Morphology, Systematics \& Ecology, Section Marine Biology, K. L. Ledeganckstraat 35, \\ B-9000 Gent, Belgium \\ ${ }^{2}$ Nederlands Instituut voor Onderzoek der Zee, Postbox 59, 1790 AB Den Burg/Texel, The Netherlands \\ ${ }^{3}$ Instituto di Biologia del Mare, CNR, Riva 7 Martiri 1364/A, I-30122 Venezia, Italy
}

\begin{abstract}
The metazoan meiofauna in the region off Kapp Norvegia, Antarctica (Weddell Sea; $71^{\circ} \mathrm{S}$, $12^{\circ} \mathrm{W}$ ), was collected from depths between 211 and $2080 \mathrm{~m}$. Total meiofaunal abundance ranged from 815 to 5122 ind per $10 \mathrm{~cm}^{2}$ and total biomass from 126 to $966 \mu \mathrm{g} \mathrm{dwt}$ per $10 \mathrm{~cm}^{2}$ Nematodes dominated the samples (range 83 to $97 \%$ ), followed by harpacticoid copepods, polychaetes and kinorhynchs. A typical skewed length frequency distribution was obtained with most nematodes in the 0.4 to $0.6 \mathrm{~mm}$ size-class. The meiofauna communities were primarily influenced by bathymetric depth and food availability (e.g. organic matter and microbiota), which in turn are suggested to be directly related to phytoplankton blooms and associated sedimentation pulses. Standing stock and distribution patterns indicate that the meiofauna from the Weddell Sea show similar features to major deep-sea assemblages elsewhere in the world.
\end{abstract}

KEY WORDS: Meiofauna $\cdot$ Continental margin · Antarctica

\section{INTRODUCTION}

The ecology of deep-sea meiofauna has been extensively studied since the first quantitative investigation by Wigley \& McIntyre (1964). Most of these studies, however, have focused on the Atlantic, Pacific and Indian Oceans (Vincx et al. 1994). So far only 2 meiofauna studies have investigated sediments from deep polar seas: one in northern boreal waters (Pfannkuche \& Thiel 1987) and one in the Weddell Sea, Antarctica (Herman \& Dahms 1992).

Compared to other oceanic regions, the pelagic of the Southern Ocean (e.g. south of $50^{\circ} \mathrm{S}$ ) has a very short, but extremely intense, summer phytoplankton bloom, often associated with the melting of the packice. As benthic communities depend heavily on the

•E-mail: sandra.verhove@rug.ac.be supply of resources from the water column, the seasonality, intensity and spatial heterogeneity of depositing matter will certainly affect the size and structure of its components. The intense pulse in primary production results in strong sedimentation of organic matter to the sea bed (Knox 1994).

From macrobenthic studies it appears that Antarctic shelf and slope sediments support high biomasses and large numbers of individuals, characterized by a relative scarceness of infaunal worms. Towards the deep sea (below $1000 \mathrm{~m}$ ) Antarctic and non-Antarctic biomass levels do not seem to differ greatly (Arntz et al. 1994).

Studies on cycling of organic matter in deep-sea sediments of the northeast Atlantic suggest degradation rates of 0.3 to $2.9 \% \mathrm{~d}^{-1}$ (Lochte 1992). Remineralization processes in the sediment mainly involve bacteria (Poremba 1994), but meiofauna also play an important role (Findlay \& Tenore 1982, Ingham et al. 1985, Alkemade et al. 1992, Giere 1993). 
The objectives of this study are (1) to assess the composition and population densities of the meiofauna off Kapp Norvegia, in the Weddell Sea 171 to $72^{\circ} \mathrm{S}, 12$ to $13^{\circ} \mathrm{W}$ ) and describe their distribution across the continental margin; (2) to compare the results with a previous study on meiofauna composition in a similar transect in the Weddell Sea to the south and west of the present study (Herman \& Dahms 1992, Halley Bay); and (3) to relate the benthic structures to events occurring in the overlying water column by comparison with other deep-sea areas in the world.

This study serves as background for a more detailed investigation on the meiofauna in the Antarctic environment. In the future, research emphasis will be on the ecological role of the most abundant and ecologically important taxon, the nematodes.

\section{MATERIAL AND METHODS}

Study area and treatment of meiofauna samples (Fig. 1, Table 1). Samples were collected off Kapp
Norvegia (Weddell Sea, 71 to $72^{\circ} \mathrm{S}, 12$ to $13^{\circ} \mathrm{W}$ ) during the third leg of the European Polarstern Study (EPOS) carried out by the RV 'Polarstern' between 13 January and 10 March 1989). General descriptions of the biological, chemical and physical characteristics of the Weddell Sea during the present investigation are given by Hempel (1993). Characteristic features of sedimentation, hydrography and topography off Kapp Norvegia are described in Grobe (1986). The investigated bathymetric range was between 211 and $2080 \mathrm{~m}$. Ice had started to retreat during the sampling period. The sediments are of glacial marine and biogenic origin (Hough 1956), and mainly consist of fine sands.

Samples were taken with a multicorer with a hydraulic system (MUC; each core $25 \mathrm{~cm}^{2}$; Barnett et al. 1984). A multiboxcorer (MG; each core $240 \mathrm{~cm}^{2}$; Gerdes 1990) was used where sampling with the more fragile multicorer was impossible, because of bad weather conditions and high sediment gravel content. The sampling device and original station numbers are included in Table 1. In both cases meiofauna was subsampled using $10 \mathrm{~cm}^{2}$ plastic cores and material was

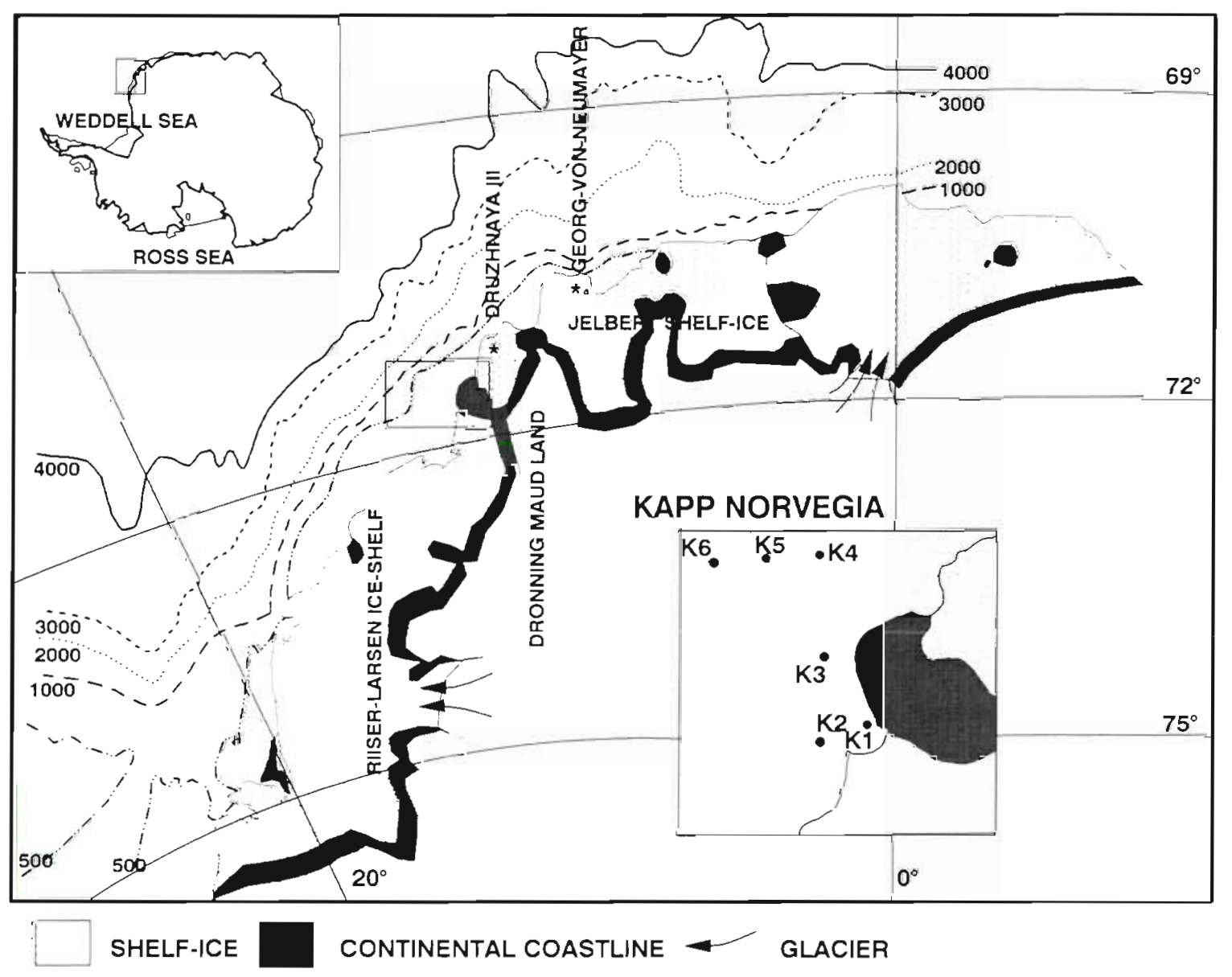

Fig. 1. Map showing the study area in the Weddell Sea, with station locations 


\begin{tabular}{|c|c|c|c|c|c|c|c|c|c|c|c|}
\hline$\vec{I}$ & $\stackrel{\infty}{\sim}$ & 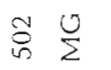 & & & & & $\stackrel{\circ}{-}$ & & & & \\
\hline$\overline{\tilde{I}}$ & $\stackrel{\leftrightarrow}{\leftrightarrow}$ & 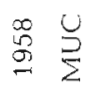 & 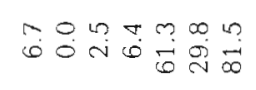 & $0: 0$ & 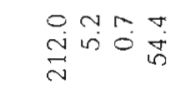 & $\ddot{0} \stackrel{\sim}{\sim}$ & $\stackrel{n}{i}$ & & 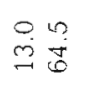 & 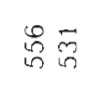 & \\
\hline$\stackrel{\Xi}{I}$ & ్ㅗำ & 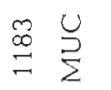 & 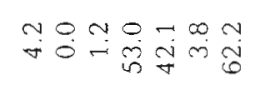 & $\stackrel{3}{0}: \overrightarrow{0}$ & $\begin{array}{l}0 \\
0 \\
\dot{D} \\
\dot{m}\end{array}$ & $\tilde{\sigma} \vec{\sim}$ & $\stackrel{a}{i}$ & & 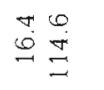 & $\stackrel{\infty}{g} \frac{9}{7}$ & \\
\hline$\stackrel{\Omega}{I}$ & $\stackrel{8}{\circ}$ & $\mathscr{L}_{\infty} \stackrel{U}{\Sigma}$ & 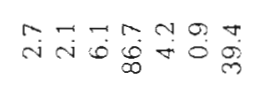 & $\begin{array}{lll}N & 0 \\
0 & 0 & 0\end{array}$ & 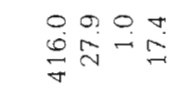 & $\ddot{0}$ & $\stackrel{\infty}{\infty}$ & & 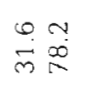 & $\vec{\sigma} \vec{i}$ & \\
\hline 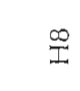 & $\stackrel{\text { I }}{\text { S }}$ & 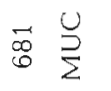 & 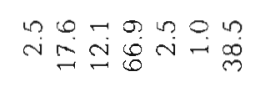 & yOd & 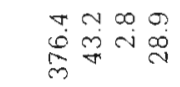 & $\overrightarrow{0} \tilde{O}$ & $\Xi$ & & $\begin{array}{l}\text { ij } \bar{x} \\
\text { in }\end{array}$ & 惌品 & \\
\hline 离咭 & $\stackrel{\infty}{N}$ & 豸ु心 & 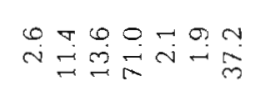 & M: & 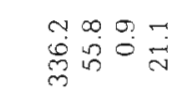 & $\stackrel{m}{0} \stackrel{0}{\circ}$ & $\vec{i}$ & & $\begin{array}{l}0 \\
0 \\
0 \\
0\end{array}$ & $\underset{\sim}{\infty} \underset{\sim}{\infty}$ & \\
\hline 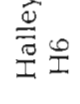 & $\stackrel{\text { In }}{N}$ & $\stackrel{U}{\stackrel{U}{Z}}$ & 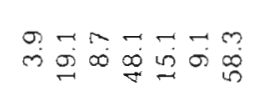 & 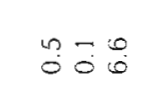 & 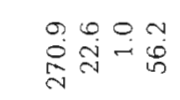 & $\vec{i}$ & $\stackrel{\mathcal{T}}{\mathrm{T}}$ & & $\begin{array}{l}30 \\
\dot{0} \\
i \\
0\end{array}$ & $\stackrel{\circ}{\stackrel{\circ}{\sigma}} \frac{\sigma}{\sigma}$ & \\
\hline 足 & $\vec{J}$ & 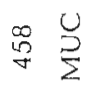 & 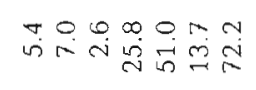 & 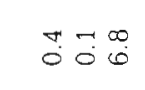 & $\begin{array}{l}0 \\
\infty \\
0 \\
m\end{array}$ & cen & $\stackrel{0}{\dot{m}}$ & & $\begin{array}{l}3 \\
\stackrel{8}{8}\end{array}$ & 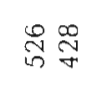 & \\
\hline 蒫 & $\stackrel{\leftrightarrow}{\sim}$ & $\stackrel{\mathscr{m}}{\stackrel{一}{\Sigma}}$ & 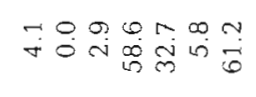 & $\begin{array}{lll}m & 0 & 0 \\
0 & 0 & 0\end{array}$ & 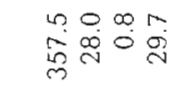 & $\overrightarrow{0}$ & & & $\frac{m}{5}$ & 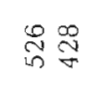 & \\
\hline$\stackrel{M}{I}$ & ஜ్లి & $\stackrel{\sim}{N} \frac{U}{\Sigma}$ & 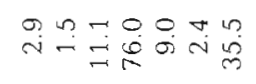 & - 000 & & & $\stackrel{\circ}{m}$ & & $\begin{array}{l}\text { 웅 } \\
\text { in in }\end{array}$ & & \\
\hline$I$ & 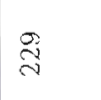 & 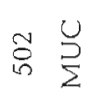 & 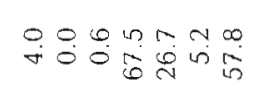 & 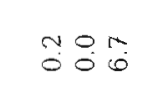 & 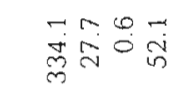 & $\stackrel{\sim}{0} \vec{m}$ & m & & 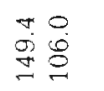 & 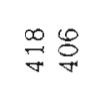 & \\
\hline$\vec{I}$ & $\stackrel{\stackrel{\sim}{N}}{ }$ & 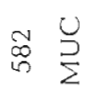 & 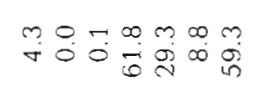 & 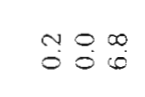 & 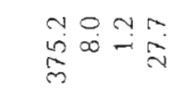 & $\square \stackrel{N}{0}$ & $\stackrel{m}{r}$ & & $\underset{\vec{m}}{\stackrel{m}{\vec{j}}}$ & $\stackrel{\infty}{8} \underset{0}{0}$ & \\
\hline 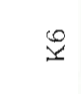 & $\stackrel{n}{\Omega}$ & 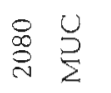 & 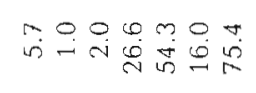 & $\ddot{0}: \overrightarrow{0}$ & 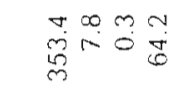 & & $\stackrel{0}{\mathrm{i}}$ & & \begin{tabular}{ll}
$n$ & 0 \\
\multirow{2}{*}{$\infty$} & 0 \\
0 & 0
\end{tabular} & 产家 & $\frac{\bar{n}}{4}$ \\
\hline$\stackrel{0}{0}$ & 容 & $\begin{array}{l}g \\
\stackrel{g}{E} \\
\vec{z}\end{array}$ & in & 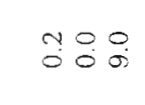 & 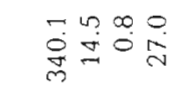 & $: ?$ & $\vec{i}$ & & 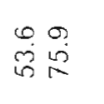 & 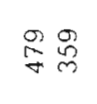 & 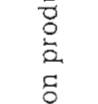 \\
\hline 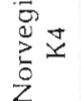 & $\stackrel{\vec{\alpha}}{2}$ & $\overrightarrow{0} \quad \frac{U}{\Sigma}$ & 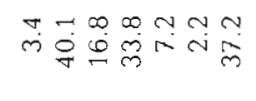 & $\ddot{5}: \stackrel{\circ}{\circ}$ & & $\stackrel{\circ}{\circ} \stackrel{n}{n}$ & gi & & & & 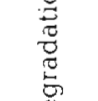 \\
\hline 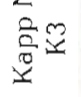 & $\stackrel{\infty}{\stackrel{\infty}{*}}$ & $\widehat{B} \bar{\Sigma}$ & 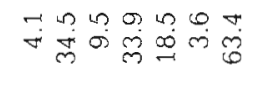 & $\ddot{0} \overrightarrow{0}$ & & $\vec{o} \vec{i}$ & $\bar{i}$ & & $\begin{array}{l}3 \\
\infty \\
\infty \\
\Leftrightarrow \\
\Leftrightarrow\end{array}$ & & 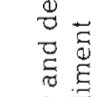 \\
\hline $\mathscr{x}$ & i & $\stackrel{?}{\sigma} \frac{U}{\Sigma}$ & 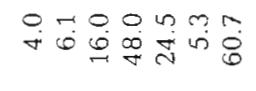 & \begin{tabular}{ccc}
$n$ & \multicolumn{1}{c}{$\infty$} \\
0 & 0 & $\infty$ \\
0 & $\infty$
\end{tabular} & 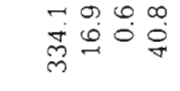 & $\overrightarrow{0} \stackrel{m}{\sigma}$ & $\stackrel{N}{m}$ & & & $\stackrel{\circ}{m} \frac{m}{m}$ & 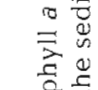 \\
\hline 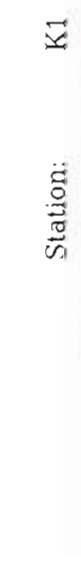 & 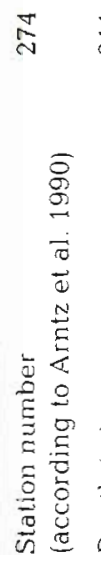 & 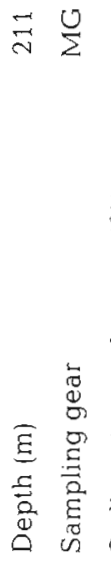 & 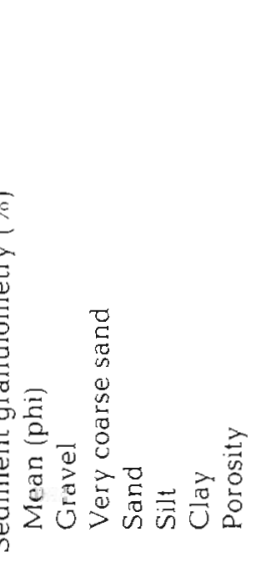 & 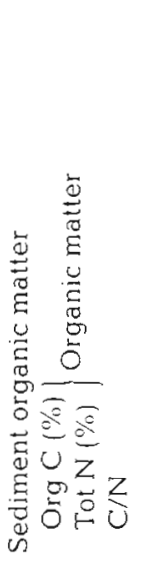 & 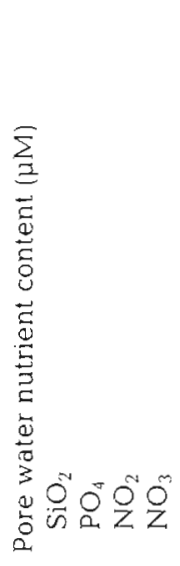 & 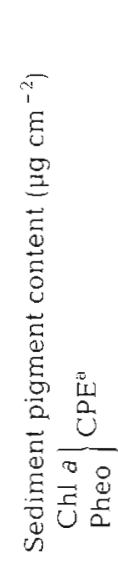 & 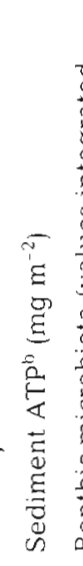 & 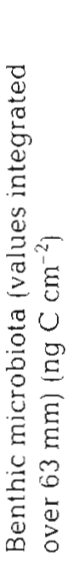 & 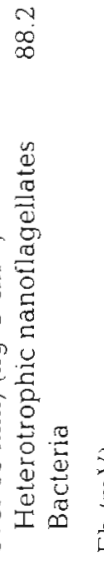 & 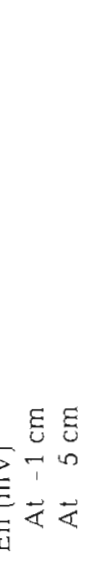 & 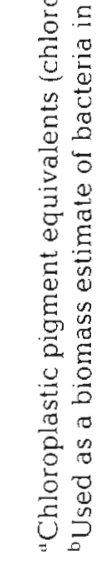 \\
\hline
\end{tabular}


held on a $38 \mu \mathrm{m}$ mesh sieve. For 6 stations at least 2 cores were analysed for both bathymetric distribution (SD is spatial distribution, bulk sediment) and vertical distribution (VD) within the sediment. The detailed descriptions of the VD replicates will be presented later. Density data presented are concerned with metazoan meiofauna. A description of the species composition of the foraminifers is given by Mateu (1992).

Approximately 200 nematodes were collected from each SD core, while 100 nematodes were used from each sediment interval for the VD analysis. After mounting the nematodes in glycerin slides (Seinhorst 1959), the length and maximum width of each individual were measured. Assuming a specific gravity of 1.13 and a $\mathrm{dry} /$ wet weight ratio of 0.25 , the biomass of nematodes was calculated using the adjusted method of Andrassy (Soetaert 1989). Parametric (ANOVA, covariance analysis) analysis was performed on respectively square and fourth root transformed data of total biomass and density. Nonparametric analysis (Kruskal-Wallis; Siegel 1956) was used on the data for individual nematode length and nematode biomass, where the assumptions for parametric analysis were not met.

Comparison with Halley Bay. Herman \& Dahms (1992) described the structure of the meiofauna along a similar depth transect in the Weddell Sea at Halley Bay. Their results were compared with the current data to assess classification techniques (Two-Way INdicator SPecies ANalysis, TWINSPAN, Hill 1979; Group-Average Sorting cluster analysis, GAS, with the Bray Curtis similarities, Bray \& Curtis 1957) using taxon composition. The stations off Kapp Norvegia are denoted with $\mathrm{K} 1$ to $\mathrm{K} 6$, the stations off Halley Bay with $\mathrm{H} 1$ to $\mathrm{H} 12$. The density data were reduced using a $4 \%$ rule (e.g. taxa consisting of less than $4 \%$ of the total density after elimination of the nematodes were excluded), and were fourth root transformed prior to this analysis (Jongman et al. 1987). The relation with environmental factors was tested using the nonparametric Spearman rank correlation analysis. Environmental data (sediment properties and microbiota) were obtained simultaneously with similar sampling devices (Table 1) For details on methods consult Arntz et al. (1990). Sediment grain size was calculated using the Wenthworth classification (Krumbein \& Pettijohn 1938)

Length and biomass of the nematodes of Halley Bay were not presented by Herman \& Dahms (1992). A summary of these data is presented in Table 3 .

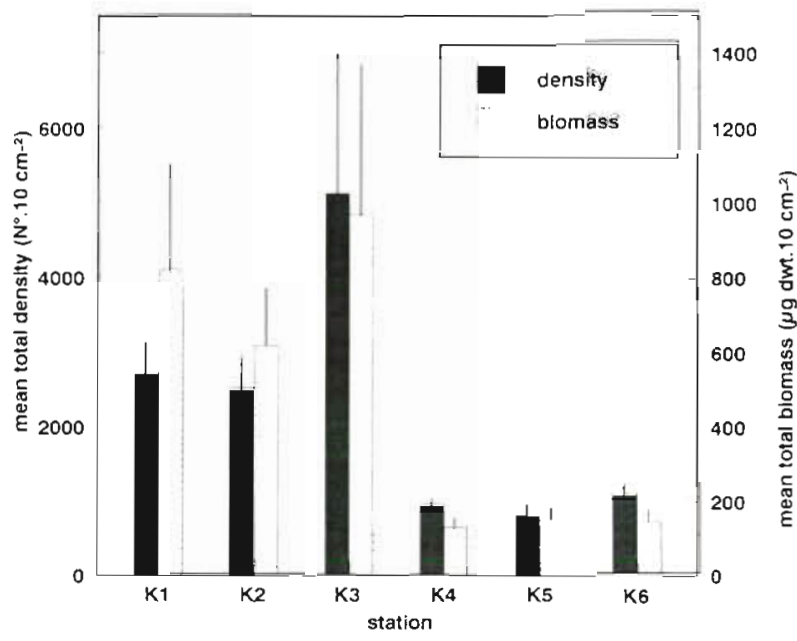

Fig. 2. Mean meiobenthos densities (no. $10 \mathrm{~cm}^{-2} \pm \mathrm{SE}$ ) and mean total biomass ( $\mu \mathrm{g} \mathrm{dwt} 10 \mathrm{~cm}^{-2} \pm \mathrm{SE}$ ) at the 6 stations

\section{RESULTS}

\section{Sample replication}

The contrast analysis (ANOVA) showed that there was no significant difference between a VD and an SD treatment ( $S D$ is bulk sediment; VD is the sum of subsequent sediment slices) of the sediment core. The exception was due to the occurrence of a small-scale spatial heterogeneity within a treatment, probably reflecting patchiness. Consequently VD and SD sam-
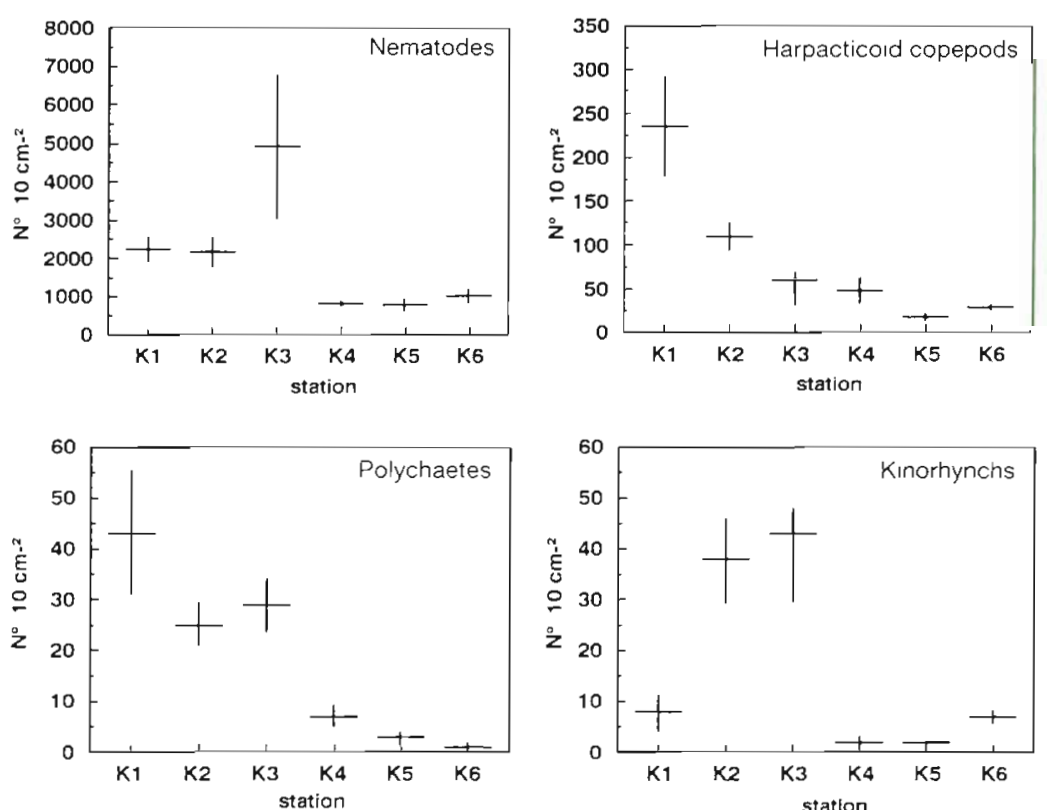

Fig. 3. Bathymetric distribution of nematodes, harpacticold copepods, polychaetes and kinorhynchs. Values shown are means $\pm \operatorname{SE}(n \geq 4)$ 
ples could be assigned as replicates the data of the VD treatments are not presented here).

\section{Distribution and composition of the meiofauna off Kapp Norvegia}

Total meiofauna densities ranged from $815 \pm 321.7$ ind $10 \mathrm{~cm}^{-2}$ at $1199 \mathrm{~m}$ depth (K5) to $5122 \pm 3254.0$ ind. $10 \mathrm{~cm}^{-2}$ at $537 \mathrm{~m}$ depth (K3). Total biomass varied from $126 \pm 47.2 \mu \mathrm{g}$ dwt $10 \mathrm{~cm}^{-2}(\mathrm{~K} 4$. $561 \mathrm{~m})$ to $966 \pm 698.6(\mathrm{~K} 3,537 \mathrm{~m}) \mu \mathrm{g} \mathrm{dwt}$ $10 \mathrm{~cm}^{-2}$. The 2 variables were significantly related to each other (dwt: abundance, $p<0.05)$. Covariance analysis showed 2 distinct groups of stations (Tukey, $p<0.001$ ). Stns K1, K2 \& K3 (Group I) had the highest densities and total biomass, while a noticeably lower stock was found in stations K4, K5 and K6 (Group II) (Fig. 2). There was no clear relationship with bathymetric depth, but 2 separate geographical groups were present: Group I was close to the ice-shelf, while Group II was more off-shore. Mean total biomass was $20 \%$ higher in Group I than in Group II. Nematodes were most abundant, and accounted for 83 to $97 \%$ of the total. They were followed by nauplii and Harpacticoidea, Polychaeta and Kinorhyncha (Fig. 3). The other taxa (19 in total) comprised together less than $4 \%$ of the total (Table 2). From this table it is clear that the diversity (number of taxa) did not differ between Groups I and II along the transect. Harpacticoid copepod and polychaete density exhibited a significant negative correlation with depth ( $p<0.01)$, whereas the nematodes and the kinorhynchs did not (Fig. 3). The distinction between the ice-shelf and open-water stations can partly be inferred from the taxon composition (Fig. 3, Table 2).

\section{Size structure of nematodes}

In order to test the hypothesis of Thiel (1975) (i.e. meiofauna become smaller in size with increasing water depth), nematode sizes were studied along the transect. The length-frequency distributions of the nematodes in the 6 stations showed similar shapes. The end stations of the transect can be considered as representatives for the whole depth transect (Fig. 4). Skewed patterns were obtained with the smaller organisms $(0.4$ to $0.6 \mathrm{~mm})$ being more highly represented. Only $27 \%$ of the nematodes were longer than $1 \mathrm{~mm}$, and only 4 and $0.9 \%$ reached lengths over 2 and $3 \mathrm{~mm}$ respectively. Mean mematode lengths varied from $743 \mu \mathrm{m}$ at $\mathrm{K} 4$ to $986 \mu \mathrm{m}$ at K1 (overall mean: $892 \mu \mathrm{m} \pm 579$; geometric mean: $754 \mu \mathrm{m}$; harmonic mean: $646 \mu \mathrm{m}$ ). The high standard deviation indicates a high variation between the replicates. Mean individual nematode lengths were significantly different
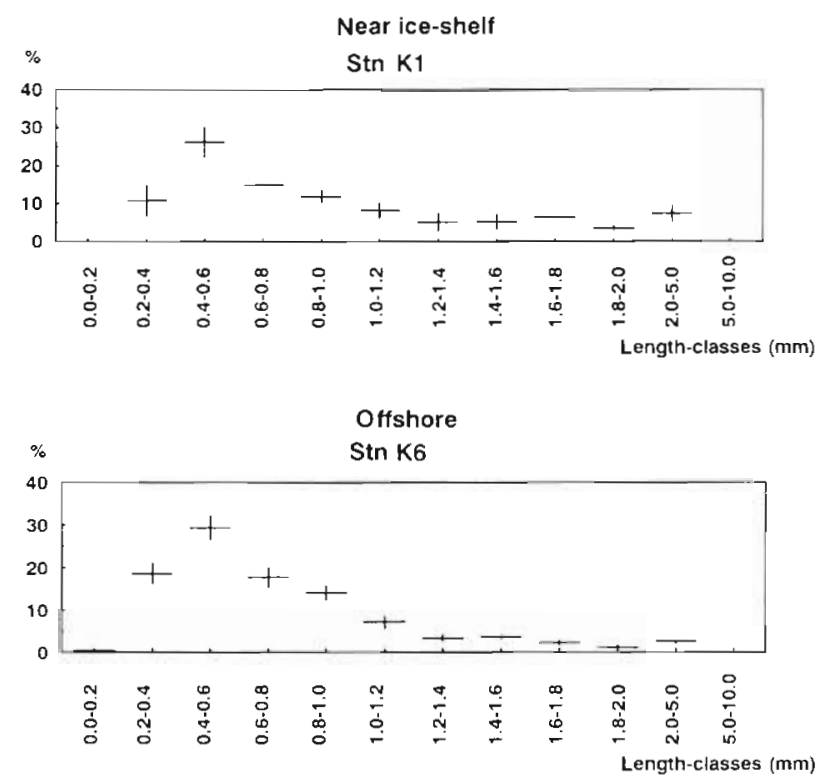

Fig. 4. Length frequency distributions of the nematodes at Stns K1 \& K6 off Kapp Norvegia (mean length in $\mathrm{mm} \pm \mathrm{SE}, \mathrm{n}=$ 3 and 5). Stns K1 \& K6 are representative of the other stations in the study 


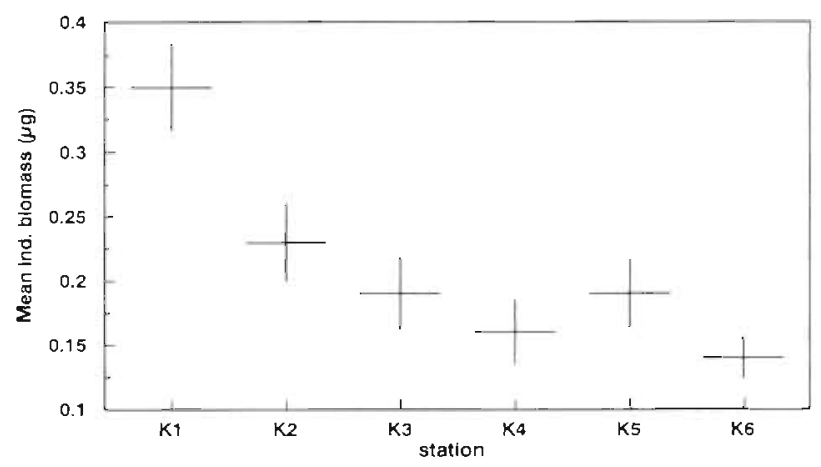

Fig. 5. Mean individual biomass ( $\mu \mathrm{g} d w t \pm S E$ ) of nematodes at each station of Kapp Norvegia

between the stations (Kruskal-Wallis, $p<0.001$ ), but were not related to bathymetric depth. This is consistent with the overall similarity in age structure of the nematodes throughout the transect (53 to $67 \%$ of the organisms were juveniles). The smallest mean individual nematode biomass per station of $0.140 \mu \mathrm{g}$ dwt at K6 shifted to $0.352 \mu \mathrm{g}$ dwt at K1 (overall mean: $0.233 \mu \mathrm{g}$

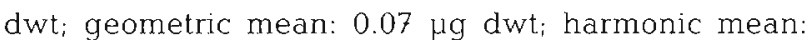
$0.03 \mu \mathrm{g} \mathrm{dwt;} \mathrm{Fig.} \mathrm{5).} \mathrm{Mean} \mathrm{individual} \mathrm{nematode} \mathrm{biomass}$ was significantly different between the stations (Kruskal-Wallis, $p<0.001$ ) and negatively correlated with water depth $(p<0.01)$.

\section{DISCUSSION}

\section{Halley Bay $\left(74\right.$ to $75^{\circ} \mathrm{S} ; 25$ to $\left.29^{\circ} \mathrm{W}\right)$ - Kapp Norvegia ( 71 to $72^{\circ} \mathrm{S} ; 12$ to $13^{\circ} \mathrm{W}$ )}

\section{Meiofauna}

Table 3 represents a comparison between the 2 regions in the Weddell Sea studied to date. The nematode community in Kapp Norvegia does not markedly differ from Halley Bay (Herman \& Dahms 1992). Only slightly higher density and biomass readings were noted in the former area. Similar conclusions can be drawn from the TWINSPAN analysis (Fig. 6), where no

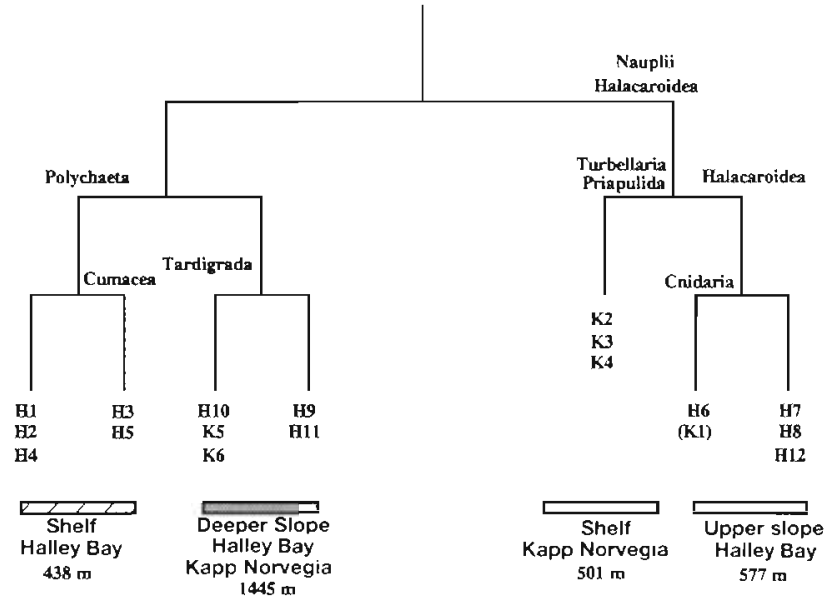

Fig. 6. TWINSPAN analysis of the samples based on the fourth-root-transformed taxon data with the indicator species (taxa) for each division indicated

clear distinction was found between the 2 transects. Clusters were primarily made on the basis of bathymetric location and/or distance to the ice-shelf, which was also relevant from the correlation analysis, and was also from observations by Herman \& Dahms (1992). A strong resemblance was found between the following areas: the shelf stations of Halley Bay ( $\mathrm{H} 1$, $\mathrm{H} 2, \mathrm{H} 3, \mathrm{H} 4, \mathrm{H} 5$; mean depth $438 \mathrm{~m}$; indicator species: polychaetes); the deeper slopes of both transects (K5, K6, H9, H10, H11; mean depth: $1445 \mathrm{~m}$ ); the shelf stations off Kapp Norvegia (K2, K3, K4; mean depth $501 \mathrm{~m}$; indicator species: turbellarians and priapulids); and the upper slope of Halley Bay (H6, H7, H8, H12 and exception $\mathrm{K} 1$, mean depth $577 \mathrm{~m}$, indicator species: halacarids). Comparable sub-divisions were obtained in the GAS analysis (not depicted), with the exception that all the shelf stations were clustered in a single group, and distinctly separated from the deeper localities (upper and deeper slope).

Meso-scale variability in the Weddell Sea

A significant correlation was found between depth and food (e.g. ATP, organic matter, heterotrophic

Table 3. Comparison of the main variables of the nematode communites between Halley Bay and Kapp Norvegia. Data given are the range values at each of the sites; means are in parentheses

\begin{tabular}{|c|c|c|}
\hline & Halley Bay (582-1958 m) & Kapp Norvegia (211-2080 m) \\
\hline Absolute density (ind per $10 \mathrm{~cm}^{2}$ ) & $730.4-2291.0(1585.7)$ & $823.8-4914.8(1993.5)$ \\
\hline Relative density $(\%)$ & $88.1-97.1 \quad(93.7)$ & $82.5-96.4 \quad(90.8)$ \\
\hline Mean individual length (mm) & $0.667-0.972 \quad(0.850)$ & $0.747-0.986 \quad(0.860\}$ \\
\hline Mean individual biomass ( $\mu \mathrm{g} \mathrm{dwt}$ ) & $0.124-0.297 \quad(0.188)$ & $0.154-0.351 \quad(0.230)$ \\
\hline Total biomass ( $\mathrm{g}$ dwt $\mathrm{m}^{-2}$ ) & $0.087-0.652 \quad(0.285)$ & $0.126-0.966 \quad(0.470\}$ \\
\hline
\end{tabular}


nanoflagellates and bacteria) on one hand, and meiofauna on the other hand (Table 4). Except for kinorhynch, nematode and oligochaete densities, meiofauna distribution was not correlated with sediment texture. Surface oxygen levels (Eh), pore water nutrients $\left(\mathrm{SiO}_{2}, \mathrm{PO}_{4}, \mathrm{NO}_{2}, \mathrm{NO}_{3}\right)$, and pigment concentrations (chlorophyll a, phaeopigments) also had little impact. High variability between sites was found in the sediment texture, nutrient pore water chemistry, microbiota (bacteria and heterotrophic nanoflagellates), and concentrations of pigments and organic matter (Table 1). Despite this, the sediments within the 4 major TWIN-groups exhibited several abiotic and biotic similarities (Fig. 7). The shelf of Halley Bay was typically characterized by high total density, high numbers of nematodes, kinorhynchs, heterotrophic nanoflagellates, intermediate nematode biomass values and very low nauplii numbers; the sediments were a mixture of silt and sand, and contained high ATP and CPE levels. The shelf of Kapp Norvegia had a dense meiofauna population, coarser sediments and high food concentrations. The deeper slopes of both transects were poor in terms of meiofauna density and biomass compared to the shelves. Low ATP, CPE and flagellate concentrations characterized the fine sediments. Total density and biomass, nematode density, and ATP in the upper slope sediments had a strong affinity with the deep localities, where generally intermediate concentrations were found. The sands were the major component of the sediment, and there was a significant occurrence of gravels. The sedimentation patterns can be related to high energy conditions due to the effect of the Antarctic Coastal Current in this zone (Rohardt et al. 1990). Such conditions prevent the deposition of finer fractions. At about $400 \mathrm{~m}$ deep off Halley Bay (Stns H4, H5, H6) active sedimentation processes were recognizable from the high values of total suspended matter observed during the cruise (Rabitti \& Boldrin 1990)

A cluster analysis on macrobenthic densities and biomass in the Weddell Sea region (Galéron et al. 1992) indicated the existence of 2 assemblages according to geographic location (e.g. southern and eastern shelf communities\}, though high variability within and between these 2 groups was found. For the same reason Gerdes et al. (1992) could not easily distinguish macrobenthic biomass from Halley Bay and Kapp Norvegia. Most stations, therefore, were grouped with the eastern shelf community described by Voß (1988), which is mainly composed of a rich and diverse community of suspension feeders, strongly dependent on depositing food particles.

Small-scale variability in the sediment

A high variation between replicates (as seen for the density and biomass of the meiofauna), was observed. This small-scale (at the $\mathrm{cm}^{2}$ level) heterogeneity, inherent to meiofauna in general (Sun \& Fleeger 1991), is likely to be strongly influenced by the microtopography and physical structure of the habitat, and hence the patchy distribution of the earlier mentioned environmental factors.

Table 4. Summary of significant Spearman rank order correlations for meiofauna variables with environmental characteristics measured: total meiofauna density; total nematode biomass; individual nematode biomass; number of taxa; nematodes (Nem.); kinorhynches (Kin.); harpacticoids (Har.); cnidarians (Cni.); priapulids (Pri.); naupliids (Nau.); oligochaetes (Ol..); tardigrades (Tar.); ostracods (Ost.); tanaidaceans (Tan.); bivalves (Biv.); polychaetes (Pol)

\begin{tabular}{|c|c|c|c|c|c|c|c|c|c|c|c|c|c|c|c|c|}
\hline & $\begin{array}{c}\text { Tot. } \\
\text { dens. }\end{array}$ & $\begin{array}{c}\text { Tot. } \\
\text { biom. }\end{array}$ & $\begin{array}{l}\text { Ind. } \\
\text { biom. }\end{array}$ & $\begin{array}{l}\text { No. } \\
\text { taxa }\end{array}$ & Nem. & Kin. & Har. & Cni. & Pri. & Nau. & Oli. & Tar. & Ost. & Tan. & Biv. & Pol \\
\hline Depth & 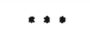 & $\cdots$ & - & $\cdots *$ & $\cdots$ & - & $*$ & - & - & * & - & $=$ & $\cdots$ & - & - & $\cdots$ \\
\hline Porosity & - & - & - & - & $\cdot$ & $\cdots$ & - & - & - & - & - & - & - & - & - & - \\
\hline Very coarse sand & - & - & - & - & - & • & - & - & - & - & - & - & - & - & - & - \\
\hline Sand & - & - & - & - & - & $\cdots$ & - & - & - & - & - & - & - & - & - & - \\
\hline Silt & - & - & - & - & - & $\cdots$ & - & - & - & - & - & - & - & - & - & - \\
\hline Clay & - & - & - & - & - & • & - & - & - & - & - & - & - & - & - & - \\
\hline $\mathrm{SiO}_{2}$ & - & - & - & - & - & - & $\cdots$ & - & - & - & - & - & - & - & - & - \\
\hline $\mathrm{NO}_{3}$ & - & - & - & - & - & - & - & - & - & • & - & - & - & * & - & - \\
\hline Eh at $-1 \mathrm{~cm}$ & $\cdot$ & - & - & - & * & • & - & - & $\cdot$ & - & -- & - & - & - & - & - \\
\hline ATP & $\cdot$ & $\cdot$ & - & - & * & * & - & - & $\cdots$ & - & - & - & - & - & - & - \\
\hline Organic carbon & - & - & - & - & - & $\cdot$ & - & - & - & - & - & - & - & $\cdots$ & - & - \\
\hline Organic nitrogen & - & - & - & - & - & $* *$ & - & - & - & - & - & - & - & $\cdots$ & - & - \\
\hline Biomass bacteria & $*$ & • & • & - & - & - & - & $*$ & * & - & - & - & $\cdot$ & $*$ & * & $\cdot$ \\
\hline Biomass flagellates & $\cdot$ & $\cdot$ & - & $\cdot$ & - & - & - & 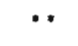 & * & - & - & - & $\bullet$ & - & $\cdots$ & $\cdots$ \\
\hline
\end{tabular}



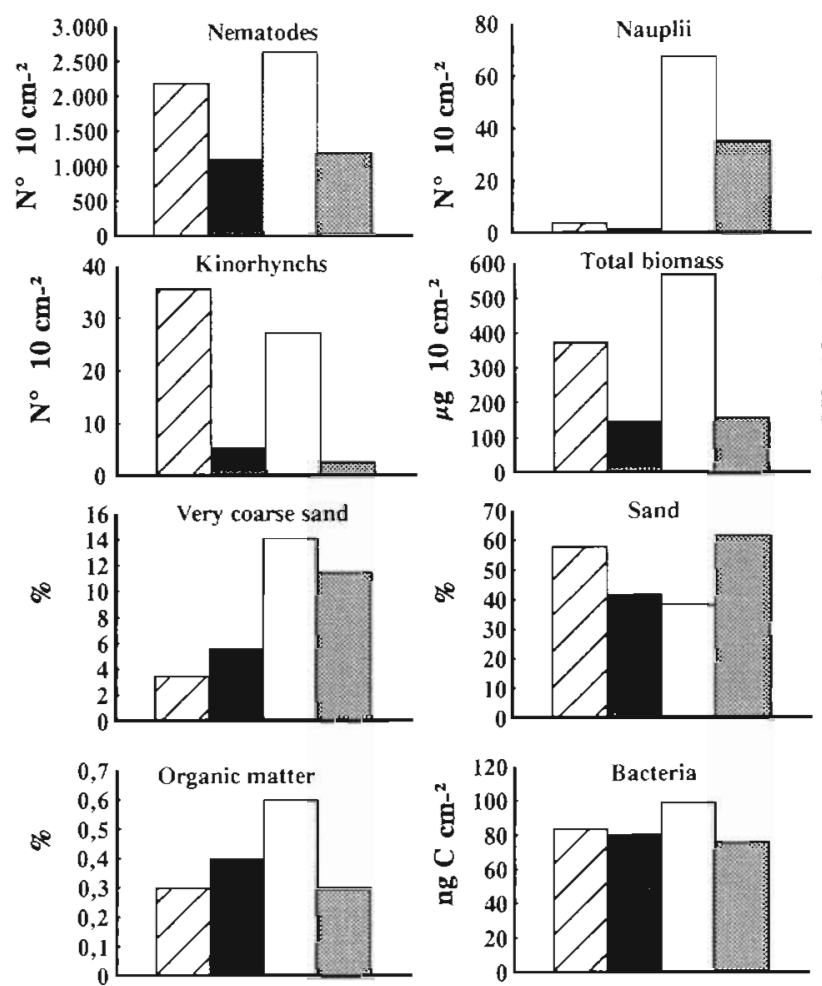

Shelf Halley Bay

Deeper slope Halley Bay + Kapp Norvegia
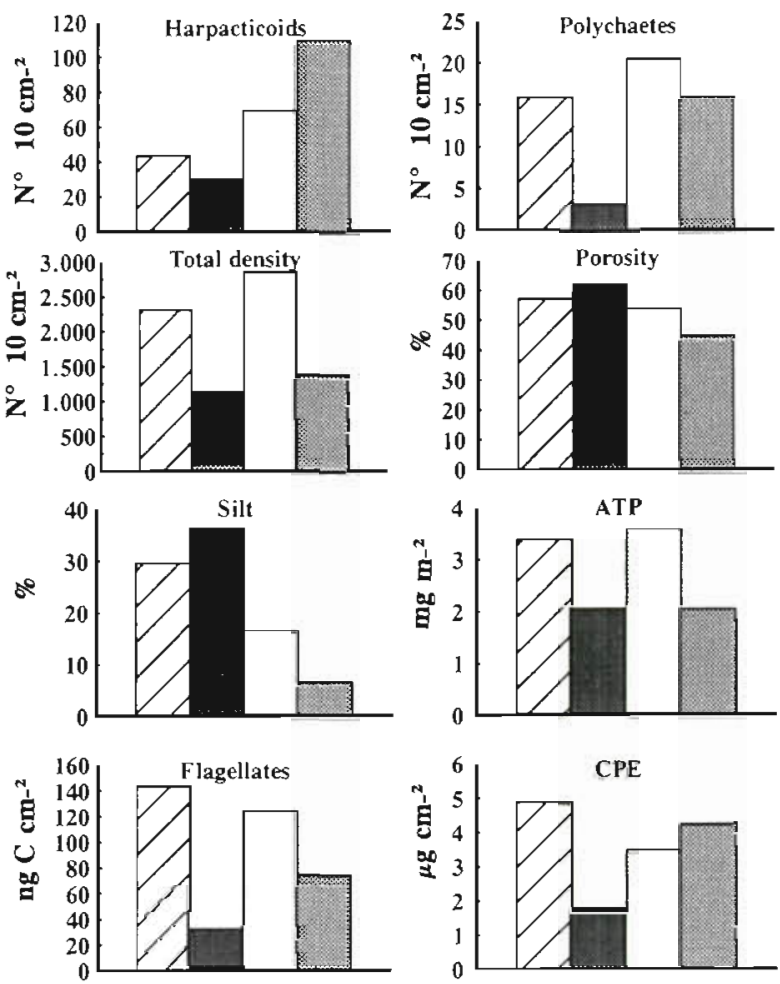

Shelf Kapp Norvegia

Upper slope Halley Bay

Fig. 7. Sediment characteristics and meiofauna densities in the 4 TWIN groups

\section{Comparison with other deep-sea areas in the world}

Meiofauna

Table 5 is restricted to transects crossing continental shelves and upper slopes (e.g. \pm 200 to $2000 \mathrm{~m}$ ). The mesh sizes of sieves were similar, except for the study of Shirayama \& Kojima (1994). As the use of different gear seriously influences the quantity of meiofauna sampled (Blomqvist 1991, Bett et al. 1994), only boxcore and multicore studies were considered. In this context it is important to note that a mixture of gear types was used in the current study (Table 1). According to Bett et al. (1994), boxcorers are less efficient collectors resulting in lower density records, with possible differences of up to $50 \%$. However, the apparent bias may vary both with time and location. From the present study it is difficult to test the difference in sampling efficiency as both types were not applied at the same sites. If such sample bias occurred, the implication is that density data obtained from multiboxcorer samples would underestimate the true population levels.

From Table 5 it is clear that the meiofauna in the Weddell Sea is characterized by densities within the range of other deep-sea environments (the upper limit of 5122 ind. $10 \mathrm{~cm}^{-1}$ is a single exceptional high value). Only the warm and oligotrophic deep-sea sediments in the Red and Mediterranean Sea had significantly poorer populations. Hence, the current results fit the regression of total metazoan meiofauna density with water depth, calculated for the northeast Atlantic Ocean (Vincx et al. 1994, Fig. 8). The composition of meiofaunal taxa turned out to be similar to that found in other deep-sea environments, with a predominance of nematodes and a relatively high importance of harpacticoids, polychaetes and kinorhynchs. A body mass of 0.05 to $0.14 \mu \mathrm{g} \mathrm{C}$ is also in accordance with dimensions of deep-sea nematodes recorded from similar depths in the east Atlantic Ocean and Norwegian Sea (Jensen 1988, Soltwedel 1993). Mean individual dwt diminished along the transect, but no correlation was found with median size. This difference is because extremely large individuals are less frequent at greater depths. These results partly support Thiel's hypothesis (1975).

\section{Environmental impact}

The factors controlling the standing stock of deepsea benthos have recently received more attention. 
Table 5. Literature data on total metazoan meiofauna density and biomass in deep seas with comparable depths. Box: (multi)boxcorer; MC: multicorer; "unicellular organisms included in total counts, "'only nematodes counted. Following Heip et al. (1985), conversion factors of $0.1,0.4$ and 0.5 were used to obtain comparable $C$ equivalents from wet wt, dwt and AFDW respectively

\begin{tabular}{|c|c|c|c|c|c|c|}
\hline Region & Source & $\begin{array}{l}\text { Depth } \\
(m)\end{array}$ & Gear & $\begin{array}{c}\text { Mesh } \\
(\mu \mathrm{m})\end{array}$ & $\begin{array}{l}\text { Density } \\
\text { (ind. } 10 \mathrm{~cm}^{-2} \text { ) }\end{array}$ & $\begin{array}{l}\text { Biomass } \\
\left(\mathrm{gC} \mathrm{m}^{-2}\right)\end{array}$ \\
\hline Mediterranean Sea & $\begin{array}{l}\text { De Bovée et al. (1990) } \\
\text { Soetaert et al. (1991). Heip et al. (1985) }\end{array}$ & $\begin{array}{l}672 \text { to } 2105 \\
160 \text { to } 1220\end{array}$ & $\begin{array}{l}\text { Box } \\
\text { Box }\end{array}$ & $\begin{array}{l}40 \\
38\end{array}$ & $\begin{array}{l}36 \text { to } 1005 \\
370 \text { to } 724\end{array}$ & 0.002 to 0.028 \\
\hline Red Sea & $\begin{array}{l}\text { Thiel (1979) } \\
\text { Thiel et al. (1987) } \\
\text { Pfannkuche (1993) }\end{array}$ & $\begin{array}{r}507 \text { to } 1977 \\
593 \text { to } 1945 \\
1223 \text { to } 1650\end{array}$ & $\begin{array}{c}\text { Box } \\
\text { Box } \\
\text { Mc+Box }\end{array}$ & $\begin{array}{l}40 \\
42 \\
40\end{array}$ & $\begin{array}{l}39 \text { to } 407 \\
43 \text { to } 195^{\circ} \\
33 \text { to } 123^{\circ}\end{array}$ & \\
\hline Pacific Ocean & Shirayama \& Kojima (1994) & 245 to 1964 & Box & 63 & 438 to $2060^{\circ}$ & \\
\hline $\begin{array}{l}\text { Atlantic Ocean } \\
\text {-NE Atlantic }\end{array}$ & $\begin{array}{l}\text { Thiel (1971) } \\
\text { Pfannkuche (1985) } \\
\text { Vanreusel et al. (1992) }\end{array}$ & $\begin{array}{l}290 \text { to } 2000 \\
500 \text { to } 2000 \\
190 \text { to } 325\end{array}$ & $\begin{array}{l}\text { Box } \\
\text { Mc } \\
\text { Box }\end{array}$ & $\begin{array}{l}42 \\
42 \\
38\end{array}$ & $\begin{array}{l}30 \text { to } 4226 \\
828 \text { to } 2604 \\
864 \text { to } 915\end{array}$ & $\begin{array}{l}0.020 \text { to } 2.850 \\
0.002 \text { to } 0.005 \\
0.055 \text { to } 0.134\end{array}$ \\
\hline$-N W$ Atlantic & Coull et al. $(1977)$ & 400 to 800 & Box & 42 & 217 to $1408^{\circ}$ & \\
\hline -SE Atlantic & Soltwedel (1993) & 551 to 1965 & Box & 42 & 277 to 1398 & 0.030 to 0.890 \\
\hline Norwegian Sea & $\begin{array}{l}\text { Dinet }(1974) \\
\text { Jensen }(1988) \\
\text { Thiel }(1975)\end{array}$ & $\begin{array}{r}283 \text { to } 2000 \\
970 \text { to } 1255 \\
1250 \text { to } 2250\end{array}$ & $\begin{array}{l}\text { Box } \\
\text { Box } \\
\text { Box }\end{array}$ & $\begin{array}{l}40 \\
45 \\
40\end{array}$ & $\begin{array}{l}139 \text { to } 971 \\
138 \text { to } 204^{\cdots} \\
600 \text { to } 1920\end{array}$ & 0.006 to 0.073 \\
\hline $\begin{array}{l}\text { Arctic Ocean } \\
\text {-Barents Sea \& } \\
\text { Nansen Basin }\end{array}$ & Pfannkuche \& Thiel (1987) & 226 to 2500 & Box & 42 & 1143 to 4339 & \\
\hline $\begin{array}{l}\text { Southern Ocean } \\
\text {-Weddell Sea }\end{array}$ & Herman \& Dahms (1992), this paper & 211 to 2080 & $\mathrm{Mc}+\mathrm{Box}$ & 38 & 815 to 5122 & 0.040 to 0.480 \\
\hline
\end{tabular}

Gage \& Tyler (1991) stated that large areas of the deep-sea floor are subjected to spatial and temporal disturbances on scales ranging from centimeters to tens of kilometers, and from days to decades or longer. The amount of biologically utilizable particulate organic matter settling from the pelagic, in particular, is a function of sedimentation and degradation rates in the water column, and determines the amplitude and

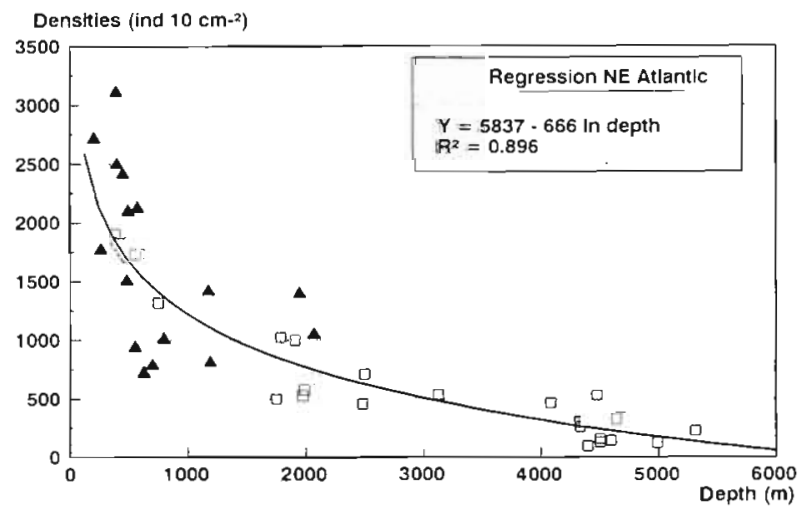

Fig. 8. Regression output of meiofaunal densities in the northeast Atlantic according to Vincx et al. (1994). Data from the Weddell Sea are added (A) but not included in the regression analysis duration of a benthic response (Lutze et al. 1986, Graf 1989, Gooday \& Turley 1990, Sayles et al. 1994, Bak et al. in press). Meiobenthic biota have been suggested to be structured by such POC flux and therefore coupled to phenomena in the pelagic (Shirayama \& Kojima 1994, Vincx et al. 1994, Soetaert \& Heip in press, Vanreusel et al. 1995).

The pelagic regime of the high Antarctic is typically characterized by sudden and pronounced bloom events. Substantial amounts of organic carbon and biogenic opal may sink as a result of high plankton death rates, current activity and melting processes in the vicinity of ice-shelves and polynyas (Fischer et al. 1988, Wefer et al. 1990). Moreover, the sedimentation of faecal pellets originating from the grazing activity of protozoans, copepods and krill is sometimes the main process for the transport of material from the surface to the sea floor in the Weddell Sea (Wefer et al. 1990). The importance of sedimentation pulses, both from the bloom and grazing, decrease with increasing distance from the shelf (Nöthig 1988, Weber 1992). In the coastal/shelf domain off Vestkapp (Weddell Sea) primary production exhibited high figures in the austral summer, ranging from 100 to $1000 \mathrm{mg} \mathrm{C} \mathrm{m} \mathrm{m}^{-2} \mathrm{~d}^{-1}$, with a maximum daily POC flux of $65 \%$ at $100 \mathrm{~m}$ depth (von Bodungen et al. 1988). For Kapp Norvegia no data on primary production 
were found, but flux rates were 3 to $110 \mathrm{mg} \mathrm{m}^{-2} \mathrm{~d}^{-1}$ at 630 m (Bathmann et al. 1991).

Substantial transport of phytodetritus to the sea bed (after ice-cover-related bloom events) and supplementary lateral transport mechanisms were thought to give rise to high concentrations of CPE in high Arctic waters (Pfannkuche \& Thiel 1987). Low temperatures induce low microbial metabolic rates, and hence low organic degradation. Therefore, according to Thiel (1983), food is available to the benthos for longer periods in these cold environments. In combination with low benthic respiration, which is thought to slow down growth rates and increase individual life spans, these high food concentrations gave rise to high meiobenthic standing stocks in the Arctic (Pfannkuche \& Thiel 1987).

The same could apply to the cold waters $\left(0.4\right.$ to $1.9^{\circ} \mathrm{C} i$ Rohardt et al. 1990) of the study area. In this region about $60 \%$ of phytoplankton derived detritus is mineralized within $16 \mathrm{~d}$ by the microbial community in the pelagic (Knox 1994). However, phytodetritus can deposit relatively rapidly and rates of 100 to $150 \mathrm{~m} \mathrm{~d}^{-1}$ have been reported (Billet et al. 1983). This result implies that a great amount of utilizable organic matter still reaches the sea bed within a few days. Concentrations of pigment and organic matter recorded in sediments in this study were, however, low (Table 3). It is likely that the sampling periods here were not immediately after phytodetrital sedimentation events. Deposited organic matter had probably been utilised by the benthic faunal assemblages. Under the assumption that primary production and POM fluxes to the sea bed showed similar features as in former years (i.e. high and very time-restricted), this would imply that benthos respond rapidly and efficiently to the episodic food supply.

\section{CONCLUSION}

Meiobenthic density and biomass data encountered in the Weddell Sea are comparable to major deep-sea environments. Features such as very high, but patchy primary production, with subsequent variable fluxes to the sea bed, induce small- and meso-scale variability between and within substrates (e.g. food resources and sediment texture), and are reflected in meiobenthic distribution patterns. It seems that the meiofauna in these regions has, therefore, developed strategies favourable to the conditions prevalent in deep-sea environments (e.g. high variability within the environment and unpredictability of food sources). Year round surveying of meiofauna and sediment properties, and a detailed investigation of age structure, metabolic activity and diversity of the populations, is now needed before further conclusions about the Antarctic deepsea meiofauna can be drawn.
Acknowledgements. The research presented in this paper was performed under the auspices of the Scientific Research Programme on Antarctica/ Phase III supported by the Belgian State-Prime Minister's Federal Offuce for Scientific, Technical and Cultural Affairs (DWTCl, and Instıtute for the Encouragement of Scientific Research in Industry and Agriculture (IWT). Samples were collected during the European 'Polarstern' Study (EPOS), sponsored by the European Science Foundation and the Alfred Wegener Institute for Polar and Marine Research. Prof. Dr A. Coomans (University of Gent) is thanked for the research facilities. The authors acknowledge H.-U. Dahms and Prof. Dr E. Schockaert for their assistance, Dr Soetaert and J. Schrijvers for their constructive comments, and Dr L. Peck for corrections of the text.

\section{LITERATURE CITED}

Alkemade R, Wielemaker W, de Jong SA, Sandee AJJ (1.992) Experimental evidence for the role of bioturbation by the marine nematode Diplolaimella dievengatensis in stimulting the mineralization of Spartina anglica detritus. Mar Ecol Prog Ser 90:149-155

Arntz W, Brey T, Gallardo VA (1994) Antarctic zoobenthos. Oceanogr mar Biol A Rev 32:241-304

Arntz W, Ernst W, Hempel I (1990) The expedition ANTARKTIS VII/4 (EPOS leg 3) and VII/5 of RV 'Polarstern' in 1989. Ber Polarforsch 68:1-214

Bak RPM, van Duyl FC, Nieuwland $\mathrm{G}$ (in press) Organic sedimentation and macrofauna as forcing factors in marine benthic nanoflagellate communities. Microb Ecol

Barnett PRO, Watson J, Connelly D (1984) A multiple corer for taking virtually undisturbed samples from shelf, bathyal and abyssal sediments. Oceamol Acta 7:399-408

Bathmann U. Fischer G. Müller PJ, Gerdes G (1991) Shortterm variation in particulate matter sedimentation off Kapp Norvegia, Weddell Sea, Antarctica: relation to water mass advection, ice cover, plankton biomass and feeding actuvity. Polar Biol 11(3):185-195

Bett BJ, Vanreusel A, Vincx $M$, Soltwedel T, Pfannkuche $O$, Lambshead PJD, Gooday AJ, Ferrero T, Dinet A (1994) Sampler bias in the quantitative study of deep-sea meiobenthos. Mar Ecol Prog Ser 104:197-203

Billet DSM, Lampitt RS, Rice AL, Mantoura RCF (1983) Seasonal sedimentation of phytoplankton to the deep-sea benthos. Nature 302:520-522

Blomqvist S (1991) Quantitative sampling of soft-bottom sed lments: problems and solutions. Mar Ecol Prog Ser 72 : 295-304

Bray JR, Curtis JT (1957) An ordination of the upland forest communities of southern Wisconsin. Ecol Monogr 27: $325-349$

Coull BC, Ellison RL, Fleeger JW, Higgins RP, Hope WD, Hummon WD, Rieger RM, Sterrer WE, Tietjen J1 1 (1977) Quantitative estimates of the mejofauna from the deep sea off North Carolina, USA. Mar Biol 39:233-240

De Bovee F, Gundı LD, Soyer J (1990) Quantitative distribution of deep-sea meiobenthos in the northwestern Mediterranean (Gulf of Lions). Cont Shelf Res 10: $1123-1145$

Dinet A (1974) Données quantitatives sur le méiobenthos bathyal de la mer de Norvège. In: Geochimie organique des sédiments marins profonds. Orgon 1, Mer de Vorvège (extract). CNRS, Paris, p 13-14

Findlay SEG, Tenore KR (1982) Effect of a free-Iiving marine nematode (Diplolaimella chitwoodi) on detrital carbon mineralization. Mar Ecol Prog Ser 8:161-166 
Fischer G, Fütterer D, Gersonde R, Honjo S, Ostermann D, Wefer G (1988) Seasonal varability of particle flux in the Weddell Sea and its relation to ice-cover Nature 335: $426-428$

Gage JD, Tyler PA (1991) Deep-sea biology, a natural history of organisms at the deep-sea floor. Cambridge University Press, Cambridge

Galéron J, l Ierman RL, Arnaud PM، Arntz WE, Hain S, Klages M (1992) Macrofaunal communities on the continental shelf and slope of the southeastern Weddell Sea, Antarctica. Polar Biol 12:283-290

Gerdes D (1990) Antarctic trials of the multi-box corer, a new device for benthos sampling. Polar Rec 26(156):35-38

Gerdes D, Klages N. Arntz WE, Herman RL, Galéron J, Hain $S$ (1992) Quantitative investigations on macrobenthos communities of the southeastern Weddell Sea shelf based on multibox corer samples. Polar Biol 12:291-301

Giere O (1993) Meiobenthology. The microscopic fauna in aquatic sediments. Springer-Verlag, Berlin

Gooday AJ, Turle:y CM (1990) Responses by benthic organisms to inputs of organic material to the ocean floor: a review. Phil Trans R Soc Lond Ser A. 331:119-138

Graf G (1989) Benthic-pelagic coupling in a deep-sea benthic community. Nature 341:437-439

Grobe H (1986) Spätpleistozäne Sedimentationsprozesse am antarktischen Kontinentalhang vor Kapp Norvegia, östliche Weddell See. Ber Polarforsch 27:7-56

Heip C, Vincx M, Vranken G (1985) The ecology of marine nematodes. Oceanogr mar Biol A Rev 23:399-489

Hempel Gi (1993) Weddell Sea ecology. Results of EPOS European 'Polarstern' Study. Springer-Verlag, Berlin

Herman RL, Dahms HU (1992) Meiofauna communities along a depth transect off Halley Bay (Weddell Sea-Antarctica) Polar Biol 12:313-320

Hill MO (1979) TWINSPAN - a FORTRAN program for arranging multivariate data in an ordered two-way table by classification of individuals and attributes. Cornell University, Ithaca, NY

Hough JL (1956) Sediment distribution in the Southern Ocean around Antarctica. J sedim Petrol 26 (4):301-306

Ingham RE, Trofymov JA, Ingham ER, Coleman DC (1985) Interactions of bacteria, fungi and their nematode grazers: effects on nutrient cycling and plant growth. Ecol Monogr 55:119-140

Jensen P (1988) Nematode assemblages in the deep-sea benthos of the Norwegian Sea. Deep Sea Res 35:253-266

Jongman RHG, ter Braak CJF, van Tongeren OFR (1987) Data analysis in community and landscape ecology. Pudoc Wageningen

Knox GA (1994) The biology of the Southern Ocean. In: Clarke A, Bliss L, Dewry DJ, Walton DWH, Williams PJ (eds) Studies in polar research. Cambridge University Press, Cambridge

Krumbein WC, Pettijohn FJ (1938) Manual of sedimentary petrography. Appleton-Century Crofts, Inc, New York

Lochte K (1992) Bacterial standing stocks and consumption of organic carbon in the benthic boundary layer of the abyssal north Atlantic. In: Rowe GT, Pariente $V$ (eds) Deep-sea food chains and the global carbon cycle, NATO ASl series C: mathematical and physical sciences, Vol 360. Kluwer Academic Publishers, Dordrecht, p 1-10

Lutze GF, Pflaumann U, Weinholz P (1986) Jungquartäre Fluktuationen der benthischen Foraminiferenfaunen in Tiefsee-Sedimenten vor NW-Afrika. Eine Reaktion auf Produktivitätsànderungen im Oberflächenwasser. 'Meteor' Forsch-Ergebn C40:163-180

Mateu G (1992) Micropaleontologia sedimentaria del mar de
Weddell. In: Lopez-Martinez J (ed) Geologia de la Antartida Occidental. Simposios T 3, III Congreso Geologico de Espana y VIII Congreso Latinoamericano de Geologia. Salamanca, Espana, 1992, p 213-227

Nöthig EM (1988) Untersuchungen zur Ökologie des Phytoplanktons im südöstlichen Weddellmeer (Antarktis) im Januar/Februar 1985. Ber Polarforsch 53

Pfannkuche O (1985) The deep-sea meiofauna of the Porcupine Seabight and abyssal plain (NE Atlantic): population structure, distribution, standing stocks. Oceanol Acta 8 (3): $343-353$

Pfannkuche $O$ (1993) Benthic response to the sedimentation of particulate organic matter at the BIOTRANS station, $47^{\circ} \mathrm{N}, 20^{\circ} \mathrm{W}$. Deep Sea Res 40:727-737

Pfannkuche $O$, Thiel $H$ (1987) Meiobenthic stocks and benthic activity on the NE-Svalbard Shelf and in the Nansen Basin. Polar Biol 7:253-266

Poremba K (1994) Simulated degradation of phytodetritus in deep-sea sediments of the NE Atlantic $\left(47^{\circ} \mathrm{N}, 19^{\circ} \mathrm{W}\right)$. Mar Ecol Prog Ser 105:291-299

Rabitti S, Boldrin A (1990) The Halley Bay-Kapp Norvegia comparison. Suspended matter and oxygen. Ber Polarforsch 68:51-66

Rohardt G, Ruhland G, Schleif U (1990) Physical oceanography. Ber Polarforsch 68:39-49

Sayles FL, Martin WR, Deuser WG (1994) Response of benthic oxygen demand to particulate organic carbon supply in the deep sea near Bermuda. Nature 371:686-589

Seinhorst J (1959) A rapid method for the transfer of nematodes from fixative to anhydrous glycerin. Nematologica 4:67-69

Shirayama Y, Kojima S (1994) Abundance of deep-sea meiobenthos off Sanriku, northeastern Japan. J Oceanogr 50:109-117

Siegel S (1956) Non-parametric statistıcs for the behavioural sciences. MacGraw-Hill \& Kogakusha Ltd, Tokyo

Soetaert K (1989) An ecological-systematical study of the deep-sea meiofauna and nematode communities in the western Meditterranean Sea. PhD thesis, University of Gent

Soetaert K. Heip C (in press) Nematode community structure of deep-sea and shelf break sites in the North Atlantic and Mediterranean sea. Mar Ecol Prog Ser

Soetaert K, Heup C, Vincx M (1991) The meiobenthos along a Mediterranean deep-sea transect off Calvi (Corsica) and in an adjacent canyon. PSZN I: Mar Ecol 12:227-242

Soltwedel T (1993) Meiobenthos und biogene Sedimentkomponenten im tropischen Ost-Atlantik. Berichte aus dem Zentrum für Meeres- und Klimaforschung der Universität Hamburg Reihe E: Hydrobiologie und Fischereiwissenschaft, no. 6

Sun B, Fleeger JW (1991) Spatial and temporal patterns of dispersion in meiobenthic copepods. Mar Ecol Prog Ser 71: $1-11$

Thiel H (1971) Häufigkeit und Verteilung der Meiofauna im Bereich des Island-Faröer. Ber dt wiss Kommn Meeresforsch $22: 99-128$

Thiel H (1975) The size-structure of the deep-sea benthos. Int Revue ges Hydrobiol (Hydrogr) 60:575-606

Thiel H (1979) First quantitative data on the deep Red Sea benthos. Mar Ecol Prog Ser 1:347-350

Thiel H (1983) Meiobenthos and nanobenthos of the deep sea. In: Rowe GT (ed) The sea, Vol 8. Wiley \& Sons, New York, p $167-230$

Thiel H, Pfannkuche O, Theeg R, Schriever G (1987) Benthic metabolism and standing stock in the central and northern Red Sea. PSZN I: Mar Ecol 8:1-20

Vanreusel A, Vincx M, Bett BJ, Rice AL (1995) Nematode bio- 
mass spectra at two abyssal sites in the NE Atlantic with a presumed contrasting food supply. Int Revue ges Hydrobiol 80(2):287-296

Vanreusel A, Vincx M, Van Gansbeke D, Gijselinck W (1992) Structural analysis of the meiobenthos communities of the shelf break area in two stations of the Gulf of Biscay (N.E. Atlantic). Belg J Zool 122 (2):185-202

Vincx M, Bett BJ, Dinet A, Ferrero T. Gooday AJ, Lambshead PJD, Pfannkuche O, Soltwedel T, Vanreusel A (1994) Meiobenthos of the deep northeast Atlantic. Adv mar Biol 30:1-88

von Bodungen B, Nöthig EM, Sui Q (1988) New production of phytoplankton and sedimentation during summer 1985 in the southeastern Weddell Sea. Comp Biochem Physiol 90B: $475-487$

This article was submitted to the editor
Voß J (1988) Zoogeographie und Gemeinschaftsanalyse des Makrozoobenthos des Weddellmeeres (Antarktis). Ber Polarforsch 45:6-129

Weber M (1992) Spätquartäre Sedimentation am Kontinentalrand des südöstlichen Weddellmeeres, Antarktis. Ber Polarforsch 109:1-66

Wefer G, Fischer G, Fütterer DK, Gersonde R, Honjo S, Ostermann D (1990). Particle sedimentation and productivity in Antarctic waters of the Atlantic sector. In: Bleil U, Thiede J (eds) Geological history of the polat oceans: Arctic versus Antarctic. Kluwer Academic Publishers, Dordrecht, p 363-379

Wigley RL, McIntyre AD (1964) Some quantitative comparisons of offshore meiobenthos and macrobenthos south of Martha's Vineyard. Limnol Oceanogr 9:485-493

Manuscript first received: March 13, 1995

Revised version accepted: May 8, 1995 